\title{
ISOLATION OF LIVE CELLS FROM DIFFERENT MICE TISSUES UP TO NINE DAYS AFTER DEATH
}

\author{
Metka Voga ${ }^{1}$, Ana Pleterski ${ }^{1}$, Gregor Majdič ${ }^{1,2 *}$ \\ ${ }^{1}$ Institute for preclinical sciences, Veterinary faculty, University of Ljubljana, Gerbiceva 60, Ljubljana, ${ }^{2}$ Institute for physiology, Medical faculty, \\ University of Maribor, Taborska 8, Maribor, Slovenia \\ ${ }^{*}$ Corresponding author, Email: gregor.majdic@vf.uni-lj.si
}

\begin{abstract}
Some limited reports suggest that cells can survive in the cadavers for much longer than it was previously thought. In our study we explored how time after death, tissue type (muscle, brain and adipose tissue), storage temperature of cadavers $\left(4^{\circ} \mathrm{C}\right.$ or at room temperature) and form of tissue storage (stored as cadavers or tissue pieces in phosphate buffered saline) affect the success of harvesting live cells from mice after death. Cells were isolated from dead tissues and grown in standard conditions. Some cells were used for RNA extraction and RT ${ }^{2}$ ProfilerTM PCR Array for cell lineage identification was performed to establish which lineages the cells obtained from post mortem tissues belong to. Results of our study showed that viable cells can be regularly isolated from muscle and brain tissue 3 days post mortem and with difficulty up to 6 days post mortem. Viable cells from brain tissue can be isolated up to 9 days post mortem. No cells were isolated from adipose tissue except immediately after death. In all instances viable cells were isolated only when tissues were stored at $4{ }^{\circ} \mathrm{C}$. Tissue storage did not affect cell isolation. Isolated cells were progenitors from different germ layers. Our results show that live cells could be obtained from mouse cadavers several days after death.
\end{abstract}

Key words: mouse; cadaver; stem cells; brain; muscle; adipose tissue

\section{Introduction}

Biological death is an irreversible cessation of circulatory and respiratory functions or irreversible cessation of all functions of the entire brain, including the brain stem (1). On the basis of biological death organ and tissue procurement can be processed. Cells that have been successfully used in donor transplantation procedures already in the eighties, were harvested very shortly, usually within 1 hour post mortem (2-4). In recent years, however, several studies have shown that viable cells can survive in the cadavers for much

Received: 19 September 2020

Accepted for publication: 15 August 2021 longer than it was previously thought. Viable cells were obtained from different mammalian species at different time periods after death. Viable cells were obtained from murine liver up to 27 hours post mortem (5) and from murine inner ear up to 10 days post mortem (6). Neural stem cells from forebrain of one day old rats were obtained up to 6 days after death (7). Silvestre et al. (8) have obtained viable cells from rabbit and pig ears up to 10 days after death. Fibroblast like cells were recovered from refrigerated goat skin up to 41 days post mortem (9) and cattle skin even up to 49 days post mortem (10). Equine tendons yielded viable stem cells up to 72 hours post mortem (11). From human, myogenic cells were isolated up to 17 days post mortem (12). Results of these studies 
suggest that viable cells survive in the cadavers in different tissues for longer time periods after death. It appears in general that viable cells survive in the tissues for longer time after death if tissues or cadavers are stored at $4^{\circ} \mathrm{C}$ and even longer when stored in liquid nitrogen (13). It is not known what is happening with cells after death. Due to the lack of studies in this area, it is not clear whether cells survive in all tissues or perhaps only in certain niches, neither is certain whether cells in the cadavers remain active or perhaps assume some dormant state. The latter was proposed by Latil et al. (12) who showed that stem cells are enriched in post mortem tissue due to cellular quiescence where cells adopt a reversible dormant state and thus possess a selective survival advantage compared with other cell types. A recent study has shown that also transcriptional activity of genes remains active for at least several hours after death. Appearance of new transcripts was shown in zebra fish and mouse cells up to 48 hours after death. Interestingly, the relative amount of gene transcripts declined gradually after death from the time of death in murine liver, while in murine brain samples, the amount of transcripts actually increased during the first hour after death. Total number of transcripts that increased in murine samples was over 500, suggesting that gene transcription also continues after death (14). However, there are no systematic studies examining the effect of time after death and different storage conditions on success of postmortem cell harvesting. The purpose of our study was therefore to establish the effect of different post mortem time points, tissue type, storage temperature and form of tissue storage on the success of harvesting live cells from mice. Finally, we investigated which lineages the cells obtained from post mortem tissues belong to.

\section{Materials and methods}

\section{Animals}

In all experiments, adult, 4 to 5 months old, male BALB/C mice were used. Only males were used in this study to reduce the number of animals. Mice were bred at Institute for preclinical sciences with water and food ad libitum in standard conditions (12:12 light dark cycle and room temperature 22 $\left.{ }^{\circ} \mathrm{C}\right)$. All animal experiments were approved by the Administration of the Republic of Slovenia for Food Safety, Veterinary Sector and Plant Protection of the Republic of Slovenia and were carried out according to ethical principles, EU directive (2010/63/EU), and NIH guidelines. Mice were euthanized by $\mathrm{CO}_{2}$. The death was confirmed by cardiac arrest. After death mice were used in two ways: some mice $(\mathrm{n}=9)$ were dissected. Approximately $150 \mathrm{~mm}^{3}$ of adipose tissue, muscle tissue (musculus quadriceps) and brain tissue from hippocampus and subventricular zone was obtained. Dissected tissues were placed in 0.01 M PBS either for storage or for cell isolation at time point 0 . Other mice $(n=9)$ were stored as whole cadavers. Whole cadavers and tissue pieces were stored for 3,6 and 9 days at $4^{\circ} \mathrm{C}$ and at room temperature $\left(20-22^{\circ} \mathrm{C}\right)$. At given time points cadavers were dissected and the same tissues as those stored in PBS (adipose, muscle and brain tissue from hippocampus and subventricular zone) were obtained. Afterwards tissues both from cadavers and those stored in PBS were further processed.

\section{Cell isolation and cell culture}

Time point 0 was used for determination of a better method for cell isolation. Tissues at time point 0 were either enzymatically digested or pieces of tissue were placed directly into tissue culture plates as tissue explants. For enzymatic digestion, tissues were dissected with scalpel into very small pieces and then incubated at $37{ }^{\circ} \mathrm{C}$ overnight in Dulbecco - modified eagle medium (DMEM, Gibco, USA) containing 0,1\% collagenase type II (Sigma Aldrich, DE). The digested tissue was centrifuged at $240 \mathrm{rcf} / \mathrm{min}$ for 4 minutes. Supernatant was discarded. Pellet was resuspended in cell culture medium containing DMEM and 20\% Fetal Bovine Serum (FBS, Gibco, USA). Cell suspension was plated into 12 - well plates and cultured at $37{ }^{\circ} \mathrm{C}$ in a $5 \% \mathrm{CO}_{2}$ incubator. For direct explantion of tissues, tissue pieces were placed into the center of 12 - well plate wells with cell culture medium. Due to considerably better isolation of cells from tissue explants, tissues from time points 3,6 and 9 were subsequently used only as tissue explants and were cultured at $37{ }^{\circ} \mathrm{C}$ in a $5 \% \mathrm{CO} 2$ incubator. Cell culture medium was changed every 2-3 days. Explants were observed daily to monitor the appearance of live cells. Isolation of cells from tissue explants at time point 0 served as positive 
control. All cell experiments were repeated 3 times - 3 different male mice for each time-point $(3,6$ or 9 days after death) and storage conditions $\left(4^{\circ} \mathrm{C}\right.$ or room temperature).

\section{RNA isolation}

RNAisolation was performed from the cells isolated from muscle, hippocampus and subventricular zone tissues. All samples were stored at $4{ }^{\circ} \mathrm{C}$ for 3 days after death. After $80-90 \%$ confluence was reached, cells were detached using cell scrapper. Cell suspension was removed from the wells and centrifuged at $240 \mathrm{rcf} / \mathrm{min}$ for 4 minutes. Pellet of cells was resuspended in DPBS and centrifuged again. Total RNA extraction was carried out using Trizol (Invitrogen, USA) according to manufacturer's protocol. The amount of extracted total RNA was measured by UV spectrophotometer (Thermo Scientific, USA) at $260 / 280 \mathrm{~nm}$ wave length.

Reverse transcription quantitative polymerase chain reaction

Following RNA isolation, reverse transcription quantitative polymerase chain reaction was performed. Reverse transcription was carried out on 2 samples from each tissue source (muscle, hippocampus and subventricular zone). In the first step, $66.5 \mathrm{ng}$ and $100 \mathrm{ng}$ of total RNA of brain and muscle tissue, respectively, was reverse transcribed into cDNA using High Capacity cDNA Reverse Transcription Kit with RNAse Inhibitor (ThermoFisher) according to the manufacturer's protocol. Negative reverse transcription controls were included. All reactions were conducted in a total volume of $20 \mu \mathrm{L}$. Conditions for reverse transcription were as suggested in the manufacturer's protocol: $25^{\circ} \mathrm{C}$ for 10 minutes, $37^{\circ} \mathrm{C}$ for 120 minutes, $85^{\circ} \mathrm{C}$ for 5 minutes. Due to very low amount of isolated RNA, $100 \mathrm{ng}$ of total RNA of each muscle sample was amplified using $\mathrm{RT}^{2}$ PreAMP cDNA Synthesis Kit (Qiagen, USA) prior to quantitative polymerase chain reaction. In the second step $\mathrm{RT}^{2}$ Profiler ${ }^{\mathrm{TM}}$ PCR Array for mouse cell lineage identification (Qiagen, USA) was performed. All $\mathrm{RT}^{2}$ ProfilerTM PCR Array amplifications were conducted in a total volume of $25 \mu \mathrm{L}$. For brain tissue, 66,5 ng cDNA was used as a template. For muscle tissue, 100 ng cDNA amplified with $\mathrm{RT}^{2}$ PreAMP cDNA Synthesis Kit (Qiagen) was used as a template. The amplification was carried out in 96 - well RT2 Profiler PCR array plates (Qiagen) with a Light Cycler 96 (Roche Life Science) using the following program: $50{ }^{\circ} \mathrm{C}$ for 2 minutes, $95{ }^{\circ} \mathrm{C}$ for 10 minutes, and 45 cycles at $95{ }^{\circ} \mathrm{C}$ for 15 seconds, $60{ }^{\circ} \mathrm{C}$ for 60 seconds. List of gene symbols and names according to Mouse Cell Lineage Identification RT2 Profiler PCR Array is presented in table 1.

\section{Results}

\section{Cell isolation at time point $O$}

Dissected tissues (adipose, muscle and brain tissue from hippocampus and subventricular zone) at time point 0 after death were first used for determination of a better method for cell isolation. Considerably fewer cells were obtained from enzymatically-digested tissues that yielded viable cells only occasionally compared to the tissues that were used as explants. Isolation of cells from tissue explants at time point 0 therefore served as positive control. In all four positive control tissues (adipose, muscle and brain tissue from hippocampus and subventricular zone), viable cells were obtained.

\section{Cell isolation at 3, 6 and 9 days after death}

In all instances at all time points cells were isolated only when tissue pieces or cadavers were stored at $4^{\circ} \mathrm{C}$. No cells were obtained from cadavers or tissue pieces when stored at room temperature. Cells from 3, 6 and 9 days after death were first observed 5 to 15 days after tissue explants were placed in the tissue culture, depending on the time of storage. Earlier observation of cell isolation correlated with earlier time point of tissue explants being placed in the tissue culture. Three days after death, viable cells were obtained from muscle tissue (Figure 1), brain tissue - hippocampus (Figure 2) and subventricular zone (Figure 3), but not from the adipose tissue. Cells from all brain tissues and muscle tissue stored as whole cadavers were obtained from all samples whereas cells from muscle tissue stored as tissue pieces were obtained in 1 out of 3 samples. Six days after death, live cells were obtained only occasionally, when stored at $4{ }^{\circ} \mathrm{C}$. Cells from muscle tissue were obtained in 2 out of 3 samples stored as 
Table 1: Gene symbols and names according to Mouse Cell Lineage Identification RT2 Profiler PCR Array

\begin{tabular}{|c|c|c|c|}
\hline $\begin{array}{l}\text { Gene } \\
\text { symbol }\end{array}$ & Gene name & $\begin{array}{l}\text { Gene } \\
\text { symbol }\end{array}$ & Gene name \\
\hline$A l b$ & Albumin & Krt14 & Keratin 14 \\
\hline Apoh & Apolipoprotein $\mathrm{H}$ & Krt19 & Keratin 19 \\
\hline Aqp1 & Aquaporin 1 & Lefty 1 & Left right determination factor 1 \\
\hline Bmp4 & Bone morphogenetic protein 4 & Map3k12 & Mitogen-activated protein kinase kinase kinase 12 \\
\hline Ccr5 & Chemokine (C-C motif) receptor 5 & Miox & Myo-inositol oxygenase \\
\hline Cd34 & CD34 antigen & Mixl1 & Mix1 homeobox-like 1 (Xenopus laevis) \\
\hline Cd3e & CD3 antigen, epsilon polypeptide & Msln & Mesothelin \\
\hline Cd79a & $\begin{array}{l}\text { CD79A antigen (immunoglobu- } \\
\text { lin-associated alpha) }\end{array}$ & Myh1 & Myosin, heavy polypeptide 1 , skeletal muscle, adult \\
\hline Chat & Choline acetyltransferase & Myh11 & Myosin, heavy polypeptide 11 , smooth muscle \\
\hline Colloa1 & Collagen, type $\mathrm{X}$, alpha 1 & Myh7 & Myosin, heavy polypeptide 7 , cardiac muscle, beta \\
\hline Comp & Cartilage oligomeric matrix protein & Myl3 & Myosin, light polypeptide 3 \\
\hline Cpa1 & Carboxypeptidase A1 & Nanog & Nanog homeobox \\
\hline Ctsk & Cathepsin $\mathrm{K}$ & Neurod1 & Neurogenic differentiation 1 \\
\hline Den & Decorin & Neurog2 & Neurogenin 2 \\
\hline$D c x$ & Doublecortin & Nkx2-2 & NK2 transcription factor related, locus 2 (Drosophila) \\
\hline Dnmt3b & DNA methyltransferase 3B & Nppa & Natriuretic peptide type A \\
\hline Dpp4 & Dipeptidylpeptidase 4 & Olig2 & Oligodendrocyte transcription factor 2 \\
\hline Eno1 & Enolase 1, alpha non-neuron & $0 t x 2$ & Orthodenticle homolog 2 (Drosophila) \\
\hline Fabp 7 & Fatty acid binding protein 7 , brain & Pdgfra & $\begin{array}{l}\text { Platelet derived growth factor receptor, alpha poly- } \\
\text { peptide }\end{array}$ \\
\hline Fgf5 & Fibroblast growth factor 5 & Podxl & Podocalyxin-like \\
\hline Foxa1 & Forkhead box A1 & Pou4f2 & POU domain, class 4, transcription factor 2 \\
\hline Foxd3 & Forkhead box D3 & Pou $5 f 1$ & POU domain, class 5 , transcription factor 1 \\
\hline Foxg 1 & Forkhead box G1 & Prom 1 & Prominin 1 \\
\hline G6pc & Glucose-6-phosphatase, catalytic & Ptcra & Pre T-cell antigen receptor alpha \\
\hline Gad1 & Glutamic acid decarboxylase 1 & Rcurn & Recoverin \\
\hline Gad2 & Glutamic acid decarboxylase 2 & Runx1 & Runt related transcription factor 1 \\
\hline Galc & Galactosylceramidase & Ryr2 & Ryanodine receptor 2 , cardiac \\
\hline Gata1 & GATA binding protein 1 & Sftpb & Surfactant associated protein B \\
\hline Gata2 & GATA binding protein 2 & Sftpd & Surfactant associated protein D \\
\hline Gata6 & GATA binding protein 6 & Slc17a6 & $\begin{array}{l}\text { Solute carrier family } 17 \text { (sodium-dependent inor- } \\
\text { ganic phosphate cotransporter), member } 6\end{array}$ \\
\hline Gbx2 & Gastrulation brain homeobox 2 & Slc17a7 & $\begin{array}{l}\text { Solute carrier family } 17 \text { (sodium-dependent inor- } \\
\text { ganic phosphate cotransporter), member } 7\end{array}$ \\
\hline Gdf3 & Growth differentiation factor 3 & Slc2a2 & $\begin{array}{l}\text { Solute carrier family } 2 \text { (facilitated glucose trans- } \\
\text { porter), member } 2\end{array}$ \\
\hline Gfap & Glial fibrillary acidic protein & Slc32a1 & $\begin{array}{l}\text { Solute carrier family } 32 \text { (GABA vesicular trans- } \\
\text { porter), member } 1\end{array}$ \\
\hline Hand 1 & $\begin{array}{l}\text { Heart and neural crest derivatives } \\
\text { expressed transcript } 1\end{array}$ & Smtn & Smoothelin \\
\hline Hand2 & $\begin{array}{l}\text { Heart and neural crest derivatives } \\
\text { expressed transcript } 2\end{array}$ & Sox 17 & SRY-box containing gene 17 \\
\hline Hes5 & $\begin{array}{l}\text { Hairy and enhancer of split } 5 \\
\text { (Drosophila) }\end{array}$ & Sox2 & SRY-box containing gene 2 \\
\hline Hnf4a & Hepatic nuclear factor 4 , alpha & Sox7 & SRY-box containing gene 7 \\
\hline Ibsp & Integrin binding sialoprotein & $T$ & Brachyury \\
\hline $\operatorname{Igf2}$ & Insulin-like growth factor 2 & Tat & Tyrosine aminotransferase \\
\hline Ins2 & Insulin II & Tyr & Tyrosinase \\
\hline Itgb4 & Integrin beta 4 & $Z f p 42$ & Zinc finger protein 42 \\
\hline Krt10 & Keratin 10 & Zic1 & Zinc finger protein of the cerebellum 1 \\
\hline
\end{tabular}


whole cadavers and in 1 out of 3 samples stored as tissue pieces. Cells from hippocampus tissue were obtained in 1 out of 3 samples stored as whole cadavers and in 1 out of 3 samples stored as tissue pieces. Cells from subventricular zone were obtained in 1 out of 3 samples stored as whole cadavers. Nine days after death live cells were obtained in one sample from hippocampus tissue of one mouse, stored as a cadaver at $4^{\circ} \mathrm{C}$. No difference in cell isolation at any time point was observed in regard whether tissue was obtained from the cadavers, or was stored as tissue pieces in PBS. Results of successful harvesting of cells from tissue explants are presented in table 2.

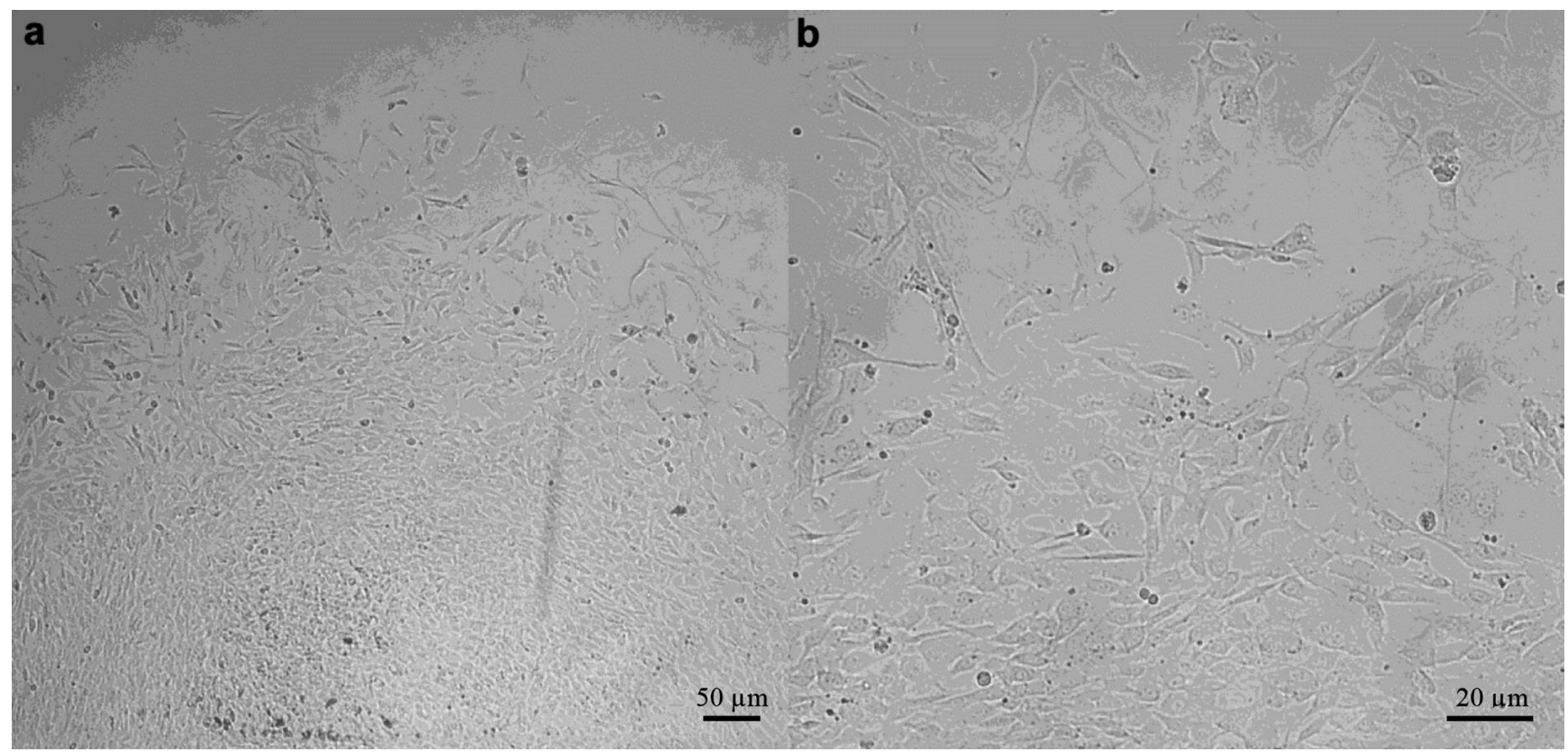

Figure 1: Cell isolation from muscle tissue stored at $4^{\circ} \mathrm{C}$ for 3 days, 17 days after seeding. A: cells coming out of muscle tissue explant. B: The same image at larger magnification

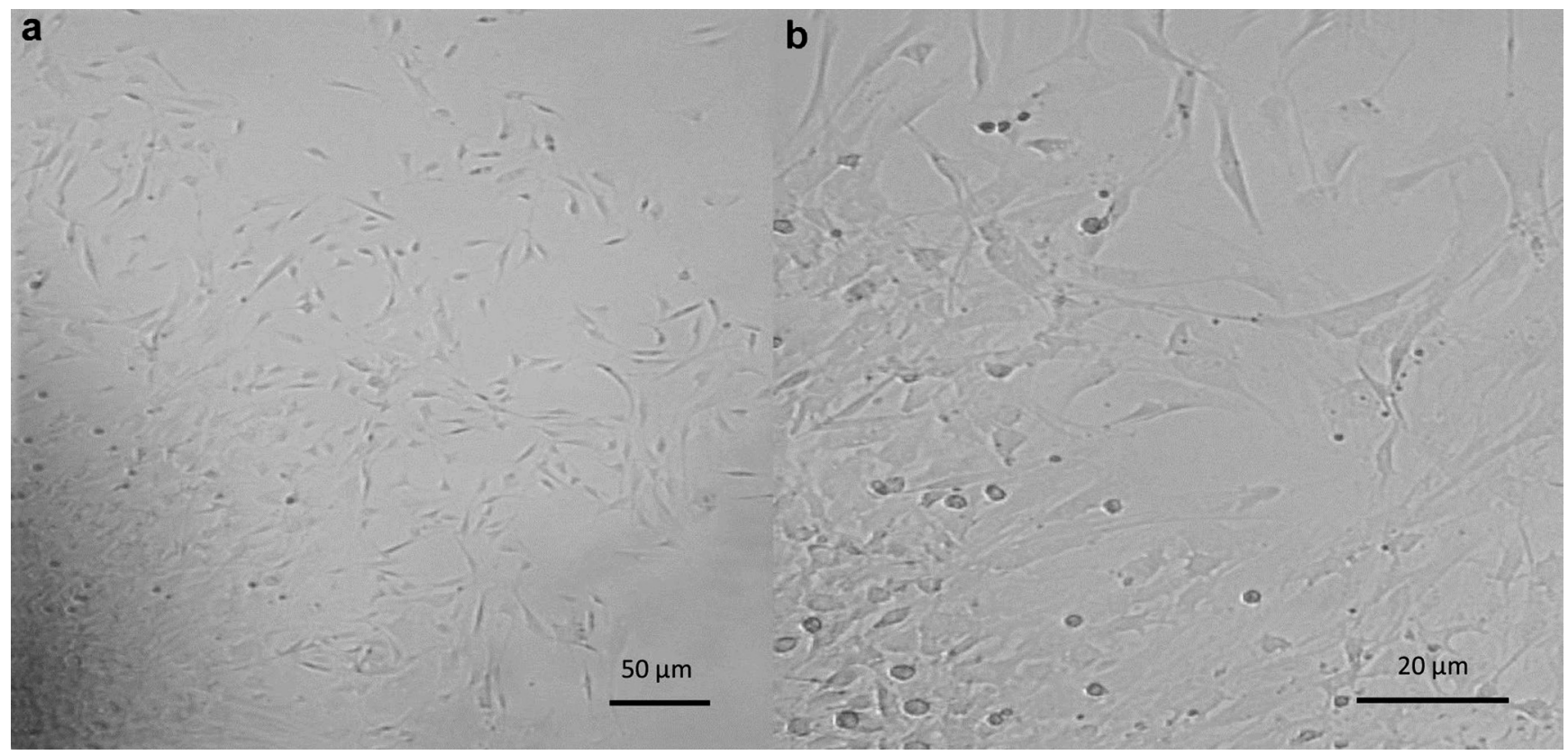

Figure 2: Cell isolation from brain tissue - hippocampus, stored at $4{ }^{\circ} \mathrm{C}$ for 3 days, 15 days after seeding. A: cells coming out of hippocampus tissue explant. B: The same image at larger magnification 


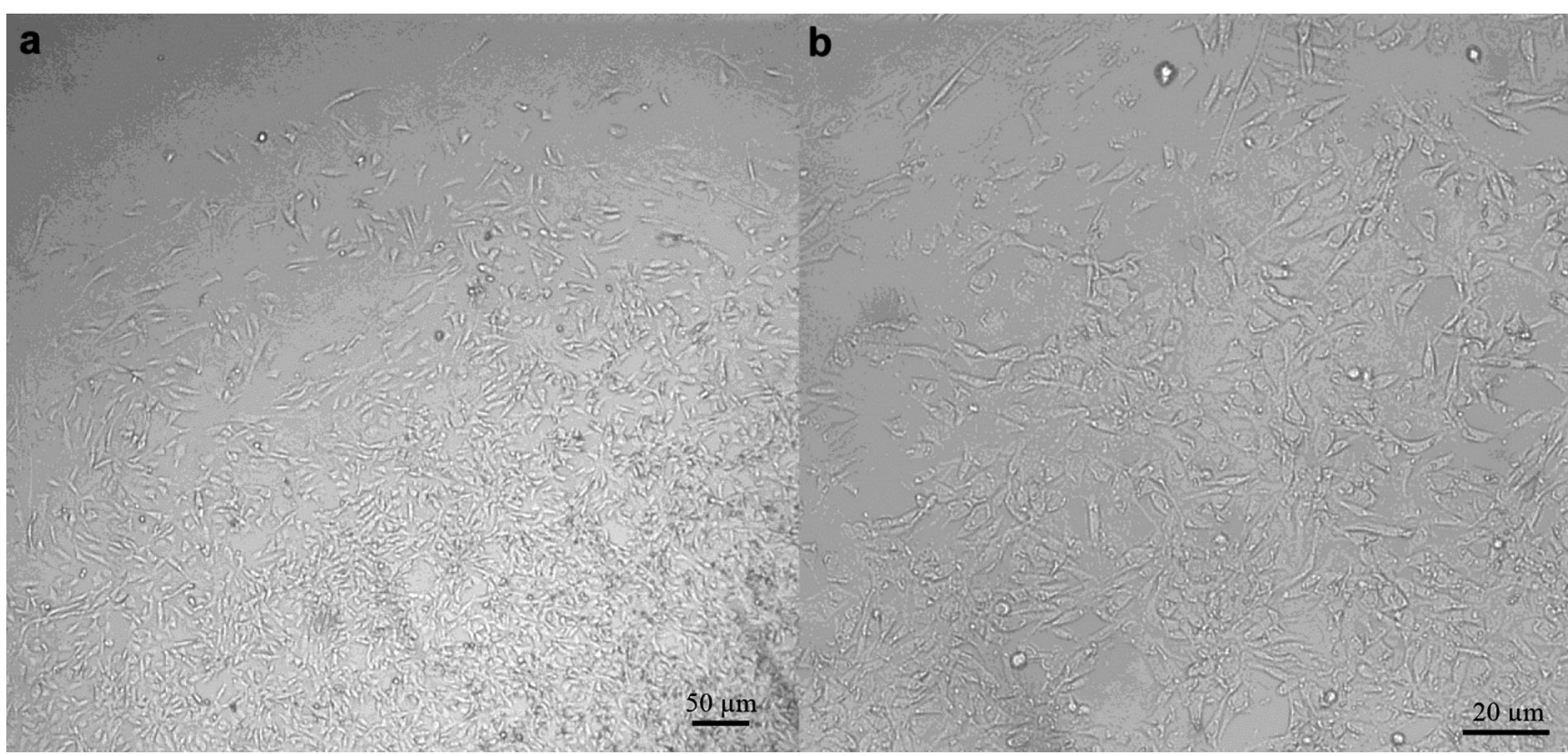

Figure 3: Cell isolation from brain tissue - subventricular zone, stored at $4{ }^{\circ} \mathrm{C}$ for 3 days, 15 days after seeding. A: cells coming out of brain tissue explant. B: The same image at larger magnification

Table 2: Number of samples from which cells were obtained regarding post mortem time points of tissue explantion, tissue type, storage temperature and form of tissue storage

\begin{tabular}{|c|c|c|c|c|c|c|}
\hline & & \multirow{3}{*}{\begin{tabular}{|c|c|c|} 
Tays \\
Tissue \\
Muscle tissue
\end{tabular}} & \multirow{3}{*}{$\begin{array}{c}0 \\
3 / 3\end{array}$} & \multirow{3}{*}{\begin{tabular}{|c|}
3 \\
$3 / 3$
\end{tabular}} & \multirow{3}{*}{$\begin{array}{c}6 \\
1 / 3\end{array}$} & \multirow{3}{*}{$\begin{array}{c}9 \\
0 / 3\end{array}$} \\
\hline & & & & & & \\
\hline \multirow{8}{*}{$\begin{array}{l}\text { Tissue pieces } \\
\text { stored in PBS }\end{array}$} & \multirow{4}{*}{$4^{\circ} \mathrm{C}$} & & & & & \\
\hline & & Adipose tissue & $3 / 3$ & $0 / 3$ & $0 / 3$ & $0 / 3$ \\
\hline & & Subventricular zone & $3 / 3$ & $3 / 3$ & $0 / 3$ & $0 / 3$ \\
\hline & & Hippocampus & $3 / 3$ & $3 / 3$ & $1 / 3$ & $0 / 3$ \\
\hline & \multirow{4}{*}{ Room temperature } & Muscle tissue & & $0 / 3$ & $0 / 3$ & $0 / 3$ \\
\hline & & Adipose tissue & & $0 / 3$ & $0 / 3$ & $0 / 3$ \\
\hline & & Subventricular zone & & $0 / 3$ & $0 / 3$ & $0 / 3$ \\
\hline & & Hippocampus & & $0 / 3$ & $0 / 3$ & $0 / 3$ \\
\hline \multirow{8}{*}{$\begin{array}{l}\text { Stored } \\
\text { cadavers }\end{array}$} & \multirow{4}{*}{$4^{\circ} \mathrm{C}$} & Muscle tissue & & $1 / 3$ & $2 / 3$ & $0 / 3$ \\
\hline & & Adipose tissue & & $0 / 3$ & $0 / 3$ & $0 / 3$ \\
\hline & & Subventricular zone & & $3 / 3$ & $1 / 3$ & $0 / 3$ \\
\hline & & Hippocampus & & $3 / 3$ & $1 / 3$ & $1 / 3$ \\
\hline & \multirow{4}{*}{ Room temperature } & Muscle tissue & & $0 / 3$ & $0 / 3$ & $0 / 3$ \\
\hline & & Adipose tissue & & $0 / 3$ & $0 / 3$ & $0 / 3$ \\
\hline & & Subventricular zone & & $0 / 3$ & $0 / 3$ & $0 / 3$ \\
\hline & & Hippocampus & & $0 / 3$ & $0 / 3$ & $0 / 3$ \\
\hline
\end{tabular}

\section{mRNA expression in isolated cells}

Mouse Cell Lineage Identification RT2 Profiler PCR Array was used to profile the expression of 84 key genes for cellular differentiation with positive PCR controls included. Genes, for which $\mathrm{Ct}$ value was 35 or lower, were marked as genes expressed.
In muscle tissue, mesoderm germ layer markers Dcn, Gata2, Pdgfra and Runx1 were expressed. Further, Cd79a, Ptcra and Cd34, mesoderm progenitor markers of early $B$ and $T$ cells and muscle stem cells were expressed, respectively. Of mesoderm terminal differentiation markers, genes encoding smooth muscle cells, osteoclasts and 
Table 3: Genes expressed in cells isolated from muscle and brain tissue. Genes for which Ct value was 35 or lower, were marked as genes expressed. Genes expressed in cells isolated from muscle tissue are marked in purple. Genes expressed in cells isolated both from muscle and brain tissue are highlighted in blue

\begin{tabular}{|c|c|}
\hline GENE ORIGIN & GENE SYMBOL \\
\hline \multicolumn{2}{|c|}{ Pluripotency markers } \\
\hline Pluripotency markers & $\begin{array}{l}\text { Dnmt3b, Gdf3 (Vgr - 2), Lefty1, Nanog, Podxl, Pou5f1 (Oct4), } \\
\text { Zfp42 }\end{array}$ \\
\hline \multicolumn{2}{|c|}{ Germ layers } \\
\hline Ectoderm & Fgf5, Foxd3, Otx2, Zic1 \\
\hline Neuroectoderm & Gbx2, Neurog2 \\
\hline Mesoderm & $\begin{array}{l}\text { Bmp4, Cd34, Dcn, Gata2, Hand1, Igf2, Mixl1, Pdgfra, Runx1, } \\
\text { Brachyury }\end{array}$ \\
\hline Endoderm & Foxa1, Gata1, Gata6, Hnf4a, Sox17, Sox7 \\
\hline \multicolumn{2}{|c|}{ Ectoderm progenitors } \\
\hline Neuronal Progenitors & Fabp7, Hes5, Prom1, Sox2 \\
\hline Immature Neurons & Dcx \\
\hline Immature GABA Neurons & Gad2, Slc32a1 \\
\hline Limbal Progenitors & Eno1, Msln \\
\hline Motor Neuron Progenitors & Foxg1, Olig2 \\
\hline Oligodendrocyte Progenitors & Nkx2-2, Olig2 \\
\hline \multicolumn{2}{|c|}{ Mesoderm progenitors } \\
\hline Early Cardiomyocytes & Hand2 \\
\hline Early B Cells & Cd79a \\
\hline Early T Cells & Cd3e, Ptcra \\
\hline Muscle Stem Cells & Cd34 \\
\hline \multicolumn{2}{|c|}{ Endoderm Progenitors } \\
\hline Pancreatic Islet Cells & Krt19 \\
\hline Hepatic Stem Cells & Apoh, Dpp4, Map3k12 \\
\hline \multicolumn{2}{|c|}{ Ectoderm Terminal Differentiation Markers } \\
\hline Keratinocytes & Krt10, Krt14 \\
\hline Melanocytes & Tyr \\
\hline Mature Neurons & Neurod1 \\
\hline Cholinergic Neurons & Chat \\
\hline GABA Neurons & Gad1 \\
\hline Glutamatergic Neurons & Slc17a6, Slc17a7 \\
\hline Astrocytes & Galc, Gfap \\
\hline Ganglion Cells & Pou4f2 \\
\hline Photoreceptor Cells & Revrn \\
\hline \multicolumn{2}{|c|}{ Mesoderm Terminal Differentiation Markers } \\
\hline Skeletal Muscle Cells & Myh1 \\
\hline Smooth Muscle Cells & Myh11, Smtn \\
\hline Cardiomyocytes & Myl3, Myh7, Nppa, Ryr2 \\
\hline Osteoblasts & Ibsp \\
\hline Osteoclasts & Ctsk \\
\hline Chondrocytes & Col10a1, Comp \\
\hline Macrophages & Ccr5 \\
\hline \multicolumn{2}{|c|}{ Endoderm Terminal Differentiation Markers } \\
\hline Hepatocytes & Alb, G6pc, Tat \\
\hline Cholangiocytes & Itgb4 \\
\hline Beta Cells & Ins2, Slc2a2 \\
\hline Exocrine Cells & Cpa1 \\
\hline Lung Cells & Sftpb, Sftpd \\
\hline Proximal Tubule Cells & Aqp1, Miox \\
\hline
\end{tabular}


chondrocytes were expressed. In addition to genes of mesodermal lineages, some genes of ectoderm and endoderm lineages were also expressed (Zic1, Gata6, Gad2, Eno1, Apoh, Map3k12, Galc, Rcvrn and Tat). In brain tissue, only expression of two genes was detected. In subventricular zone, gene Eno1, an ectoderm progenitor marker of limbal progenitors was expressed and in hippocampus, gene Rcvrn, an ectoderm terminal differentiation marker of photoreceptor cells was expressed. Results of gene expression from muscle and brain tissue derived cells are presented in table 3 .

\section{Discussion}

In the present study, we examined the differences between time after death, storage temperature and form of tissue storage in obtaining live cells from mice post mortem. Results of our study suggest that cells from muscle and brain tissue can be isolated from murine cadavers or tissue pieces up to 3 days post mortem and with difficulty up to 6 days post mortem. Cells from brain tissue can possibly be isolated even up to 9 days post mortem. Several other studies have also shown that cells from brain and muscle tissue can be isolated from cadavers from different species after different post mortem periods. The longest post mortem time period that still allows for cell isolation from muscle tissue was reported by Latil et al. (12) who showed that viable and functional murine skeletal myogenic cells can be isolated up to 14 days post mortem. Interestingly, this is much longer time period in which cells were isolated post mortem compared to our study. But similarly as in our study, it was shown by Xu et al. (7) that neural stem cells of subventricular zone from deceased rats can also be isolated for up to 6 days post mortem, but not longer, in young rats. Time period in which cells were isolated was longer in young in comparison to old rats. In our study adult mice were used. It is possible that mice age in our study shortened the post mortem time periods in which cells were isolated as in most previous studies including study by Latil et al. (12) younger mice were used. Contrary to rodent neuronal stem cells, cells from human brain tissue are reported to be able to survive only up to 36 hours post mortem $(15,16)$, which suggests that post mortem time periods of neuronal stem cells from rodents might be longer than that of humans. This suggests that for some cell types post mortem time period of cell isolation might be species specific. Contrary, some studies indicate that post mortem time period might also be tissue specific. For example, it was shown by Latil et al. (12) that the longest post mortem time period of cell isolation from human muscle tissue was 17 days, which means it was not only similar to but it even exceeded the time period in which murine cells were isolated. Furthermore, it was shown by Erker et al. (5) that post mortem time periods of isolated hepatocytes do not differ between murine, rhesus macaque monkeys and humans. The lack of studies to compare post mortem isolation of cells from different species and tissues and different methods used in studies hinder speculation whether certain post mortem time period of cell isolation is species or tissue specific.

To our knowledge there are no studies in which comparison of different tissues regarding post mortem cell isolation from one species were studied. In our study, no significant difference was observed regarding post mortem time period for isolation of cells from brain and muscle tissue. In addition to brain, muscle and liver tissue, cells from other tissues have also been isolated post mortem, such as human retinal progenitor cells (immediately post mortem) (17), murine vestibular and cochlear stem cells (up to 10 days post mortem) (6), equine ligament stem cells (up to 72 hours post mortem) (11) and bovine skin fibroblast like cells (up to 49 days post mortem) (10).

Interestingly there are no reports of adipose tissue derived cells isolated post mortem, although adiposetissueisan excellent sourceofmesenchymal stem cells / multipotent mesenchymal stromal cells in different species. In our study adipose tissue yielded cells only immediately post mortem, but no cells were isolated at other time points after death, suggesting that cells in adipose tissue do not survive long after death. One possible reason for unsuccessful harvesting of adipose derived cells from mice post mortem in our study could be unsuitable anatomical site from which adipose tissue was obtained, since it was shown that there are intrinsic differences in adipocyte precursor cells from different white fat depots in mice (18) and that the concentrations of adipose derived stem cells from human cadavers differ between sites (19). Several studies have also shown that anatomical site of adipose tissue harvesting from live organisms is an important factor in terms of 
differentiation potential, viability, yield and stem cell capacity (20-23), although there are no studies available comparing adipose tissue harvesting from different anatomical sites from BALB/C mice. Effect of different anatomical origins of adipose tissue on stem cell features could also reflect in the possibility of cells being harvested post mortem, although no studies are available on this topic. Another reason for unsuccessful obtaining of adipose derived cells could be in the adipose tissue differences between inbred mouse strains, as was shown in a study by Mo et al. (24), who compared the frequency of proliferative stromal cells in $129 \times 1 /$ svj and $\mathrm{C} 57 \mathrm{Bl} / 6 \mathrm{~J}$ mice. But comparison of adipose derived cell characteristics between BALB/C and other mouse strains is yet to be studied.

In the present study, cells from muscle and brain tissues were isolated only when tissue pieces or cadavers were stored at $4^{\circ} \mathrm{C}$. No cells were obtained from cadavers or tissue pieces when stored at room temperature, suggesting that low temperatures preserve the cells in cadavers or tissue pieces while higher (room) temperatures promote cell death. In most studies where post mortem cell isolation was examined, cells were harvested immediately after death for donor transplantation procedures $(2-4,25)$, or after longer periods of time after cadavers were stored at $4^{\circ} \mathrm{C}(5,7)$. Interestingly, in some cases, where cells were successfully isolated from murine inner ear and human muscle tissue or arteries long after death, cadavers were kept at room temperature from 6 to 12 hours before they were stored at lower temperatures for later harvesting of cells $(6$, $12,13)$, suggesting that shorter period at room temperature is compatible with obtaining viable cells while longer periods (as in our study) decrease the viability of cells in cadavers. Interestingly, in a recent study fibroblast - like cells were recovered up to 15- and 49-days postmortem from bovine skin stored at $25^{\circ} \mathrm{C}$ and $4^{\circ} \mathrm{C}$, respectively (10). Although we were unable to obtain live cells when cadavers or tissue pieces were stored at room temperature, it seems that in some cases, stem cells can survive even after cadavers are stored for certain time periods at room temperature.

In most of the studies where cells were harvested at certain time points after death, animal or human subjects were stored in cadaveric form. In others, cadavers were dissected prior to experiment and tissue pieces were stored. There are, however, no studies in which affect of form of storage on cell isolation was investigated in the same study. In our study, no difference in cell isolation between two forms of storage was observed.

To find out which cells were isolated in our study, we used Mouse Cell Lineage Identification RT2 Profiler PCR Array that profiles the expression of 84 key genes for cellular differentiation. Array contains gene markers for specific cell types throughout cellular lineage progression, including pluripotent stem cells, progenitor cells from each of the three germ layers, and terminally differentiated cells. Results from qPCR suggests that from muscle and brain tissue, cells with characteristics of germ layer cells, progenitor cells and terminally differentiated cells were isolated. Cells obtained from brain tissue seem to be ectodermal progenitors and ectodermal terminally differentiated cells. In cells isolated from muscle tissue there was the strongest expression of markers for mesoderm germ layer, mesoderm progenitors and mesoderm terminally differentiated cells. However, cells isolated from muscle tissue also expressed some genes from ectodermal and endodermal lineages, possibly suggesting that heterogenous population of cells was obtained from muscle tissue. In general expression of all markers was low, possibly due to low amount of RNA obtained from the cells, and genes that were expressed in these cells were heterogenous. Therefore, it was not possible to exactly determine the lineage of cells obtained from dead mice, possibly suggesting that different types of cells were obtained, and further studies will be needed to more carefully examine the lineage and characteristic of cells obtained post mortem.

Despite the fact that heterogenic lineage population of cells from muscle tissue was isolated, it was concluded that, regardless of their origin, cells can be readily isolated from muscle and brain tissue 3 days post mortem. Although with difficulty, cells from muscle and brain tissue can also be isolated up to 6 days post mortem, and possibly even up to 9 days post mortem from brain tissue. Our results are consistent with results of other studies that showed that cells survive in the dead organisms for longer time after death than it was previously thought. In majority of the studies focusing on post mortem cell isolation, stem cells were obtained. It is presumed that, for example in satellite cells, the lack of oxygen, nutrients, or the 
presence of extensive necrosis triggers a cellular response in stem cells resulting in their adopting a deeper state of quiescence or dormancy (12). Similarly, the possibility of post mortem neural stem cell isolation is ascribed to low metabolic level of neuronal stem cells and rich vascular bed in subventricular zone and surrounding tissues (7), which could act as a niche for neuronal stem cells (15). Hypoxia, which is prevalent in muscle stem cell niches (27) as well as in niches of other stem cells such as neuronal stem cells (28), is an important factor that contributes to cell viability and regeneration potential that could maintain stem cell viability for unusually long periods in spite of the necrotic microenvironment. Stem cells are thus assumed to be enriched in post mortem tissue due to cellular quiescence where cells adopt a reversible dormant state and thus possess a selective survival advantage compared with other cell types (12). Contrary to these studies we showed, based on gene expression results, that not only stem cells but also terminally differentiated cells survive in post mortem tissues for at least 3 days after death.

In conclusion, in this study we showed that (1) cells from murine animals can be isolated from muscle and brain tissue readily 3 days post mortem and with difficulty up to 6 days post mortem. Cells from brain tissue can possibly be isolated even up to 9 days post mortem (2). Compared to muscle and brain tissue no cells were isolated post mortem from adipose tissue except immediately after death (3). In all instances cells were isolated only when tissues were stored at $4{ }^{\circ} \mathrm{C}$. 4) Form of tissue storage does not affect cell isolation (5). Not only stem cells but also terminally differentiated cells seem to survive in post mortem tissues for at least 3 days after death.

\section{Acknowledgments}

This study was supported by ARRS grant P40053 and Metka Voga is supported by ARRS Ph.D. fellowship. We are grateful to Nina Sterman for technical assistance.

The datasets supporting the results of this document are contained within the article. Any additional data may be requested to the corresponding author.

All animal experiments were approved by the Administration of the Republic of Slovenia for Food Safety, Veterinary Sector and Plant Protection of the Republic of Slovenia and were done according to ethical principles, EU directive (2010/63/EU), and NIH guidelines.

All authors declared that they have no competing interests.

MV and AP performed the experiments. GM planned the experiments and analyzed the data together with MV and AP. MV and GM drafted the manuscript, which was edited and approved by all authors.

\section{References}

1. Leming MR, Dickinson GE. Understanding dying, death, and bereavement. 4th. ed. Fort Warth : Harcourt Brace College Publishers, 1998: 518 str.

2. Blazar BR, Lasky LC, Perentesis JP, et al. Successful donor cell engraftment in a recipient of bone marrow from a cadaveric donor. Blood 1986; 67(6): 1655-60. doi: 10.1182/blood.V67.6.1655.1655

3. Ciancio G. Donor bone marrow infusion in cadaveric renal transplantation. Transplant Proc 2003; 35(2): 871-2. doi: 10.1016/s00411345(02)04034-4

4. Kapelushnik J, Aker M, Pugatsch T, Samuel $\mathrm{S}$, Salvin S. Bone marrow transplantation from a cadaveric donor. Bone Marrow Transplant 1998; 21: 857-8. doi: 10.1038/sj.bmt.1701165

5. Erker L, Azuma H, Lee AY, et al. Therapeutic liver reconstitution with murine cells isolated long after death. Gastroenterology 2010; 139(3): 101929. doi: $10.1053 /$ j.gastro.2010.05.082

6. Senn P, Oshima K, Teo D, Grimm C, Heller S. Robust postmortem survival of murine vestibular and cochlear stem cells. J Assoc Res Otolaryngol 2007; 8(2): 194-204. doi: 10.1007/s10162007-0079-6

7. Xu Y, Kimura K, Matsumoto N, Ide C. Isolation of neural stem cells from the forebrain of deceased early postnatal and adult rats with protracted post-mortem intervals. J Neurosci Res 2003; 74: 533-40. doi: 10.1002/jnr.10769

8. Silvestre MA, Saeed AM, Cervera RP, Escribá MJ, García-Ximénez F. Rabbit and pig ear skin sample cryobanking: Effects of storage time and temperature of the whole ear extirpated immediately after death. Theriogenology 2003; 59(5/6): 1469-77. doi: 10.1016/s0093-691x(02)01185-8

9. Okonkwo C, Singh M. Recovery of fibroblast-like cells from refrigerated goat skin up to $41 \mathrm{~d}$ of animal death. In Vitro Cell Dev Biol Anim 2015; 51(5): 463-9. doi: 10.1007/s11626-0149856-9 
10. Walcott B, Singh M, Hatti Kaul R. Recovery of proliferative cells up to 15 - and 49-day postmortem from bovine skin stored at $25^{\circ} \mathrm{C}$ and $4{ }^{\circ} \mathrm{C}$, respectively. Cogent Biol 2017; 3(1): e1333760. doi: 10.1080/23312025.2017.1333760

11. Shikh Alsook MK, Gabriel A, Piret J, et al. Tissues from equine cadaver ligaments up to 72 hours of post-mortem: a promising reservoir of stem cells. Stem Cell Res Ther 2015; 6: e253. doi: 10.1186/s13287-015-0250-7

12. Latil M, Rocheteau $\mathrm{P}$, Chatre $\mathrm{L}$, et al. Skeletal muscle stem cells adopt a dormant cell state post mortem and retain regenerative capacity. Nat Commun 2012; 3: e903. doi: 10.1038/ ncomms 1890

13. Valente S, Alviano F, Caivarella C, et al. Human cadavermultipotent stromal/stem cells isolated from arteries stored in liquid nitrogen for 5 years. Stem Cell Res Ther 2014; 5(1): e8. doi: $10.1186 /$ scrt397

14. Pozhitkov AE, Neme R, Domazet-Loso T, et al. Tracing the dynamics of gene transcripts after organismal death. Open Biol 2017; 7(1): e160267. doi: 10.1098/rsob. 160267

15. Palmer TD, Schwartz PH, Taupin P, Kaspar B, Stein SA,Gage FH. Progenitor cells from human brain after death. Nature 2001; 411(6833): 42-3. doi: 10.1038/35075141

16. Schwartz PH, Bryant PJ, Fuja TJ, Su H, O'Dowd DK, Klassen H. Isolation and characterization of neural progenitor cells from post-mortem human cortex. J Neurosci Res 2003; 74(6): 838-51. doi: 10.1002/jnr.10854

17. Klassen H, Ziaeian B, Kirov, II, Young MJ, Schwartz $\mathrm{PH}$. Isolation of retinal progenitor cells from post-mortem human tissue and comparison with autologous brain progenitors. J Neurosci Res 2004; 77(3): 334-43. doi: 10.1002/jnr.20183

18. Macotela Y, Emanuelli B, Mori MA, et al. Intrinsic differences in adipocyte precursor cells from different white fat depots. Diabetes 2012; 61: 1691-9. doi: 10.2337/db11-1753/-/DC1

19. Kishi K, Imanishi N, Ohara H, et al. Distribution of adipose-derived stem cells in adipose tis- sues from human cadavers. J Plast Reconstr Aesthet Surg 2010; 63(10): 1717-22. doi: 10.1016/j. bjps.2009.10.020

20. Prunet-Marcassus B, Cousin B, Caton D, Andre M, Penicaud L, Casteilla L. From heterogeneity to plasticity in adipose tissues: Site-specific differences. Exp Cell Res 2006; 312(6): 727-36. doi: $10.1016 / j$.yexcr.2005.11.021

21. Chen L, Peng EJ, Zeng XY, Zhuang QY,Ye $Z Q$. Comparison of the proliferation, viability, and differentiation capacity of adipose-derived stem cells from different anatomic sites in rabbits. Cells Tissues Organs 2012; 196(1): 13-22. doi: 10.1159/000330796

22. Tsekouras A, Mantas D, Tsilimigras DI, Moris D, Kontos M, Zografos GC. Comparison of the viability and yield of adipose-derived stem cells (ascs) from different donor areas. In Vivo 2017; 31(6): 1229-34. doi: 10.21873/invivo.11196

23. Reumann MK, Linnemann C, Aspera-Werz $\mathrm{RH}$, et al. Donor site location is critical for proliferation, stem cell capacity, and osteogenic differentiation of adipose mesenchymal stem/stromal cells: Implications for bone tissue engineering. Int J Mol Sci 2018; 19(7): e1868. doi: 10.3390/ ijms 19071868

24. Mo J, Srour EF, Rosen ED. The frequency of proliferative stromal cells in adipose tissue varies between inbred mouse strains. J Stem Cells Regen Med 2009; 5(1): 23-9. doi: 10.46582/jsrm.0501005

25. Michalova J, Savvulidi F, Sefc L, Forgacova K, Necas E. Cadaveric bone marrow as potential source of hematopoietic stem cells for transplantation. Chimerism 2011; 2(3): 86-7. doi: 10.4161/ chim.2.3.17917

26. Gustafsson MV, Zheng X, Pereira T, et al. Hypoxia requires notch signaling to maintain the undifferentiated cell state. Dev Cell 2005; 9(5): 617-28. doi: 10.1016/j.devcel.2005.09.010

27. Mohyeldin A, Garzon-Muvdi T,Quinones-Hinojosa A. Oxygen in stem cell biology: a critical component of the stem cell niche. Cell Stem Cell 2010; 7(2): 150-61. doi: 10.1016/j. stem.2010.07.007 


\title{
IZOLACIJA ŽIVIH CELIC IZ RAZLIČNIH TKIV MIŠI DO DEVET DNI PO SMRTI
}

\author{
M. Voga, A. Pleterski, G. Majdič
}

Izvleček: Nekatere raziskave kažejo, da je preživetje celic v truplih precej daljše, kot je bilo znano do sedaj. V naši raziskavi smo proučevali, kako na uspešnost izolacije živih celic po smrti miši vplivajo različen čas izolacije po smrti, vrsta tkiva (mišično, možgansko in maščobno), temperatura shranjevanja trupel ter oblika shranjenega tkiva (kot koščki tkiv ali kot celi kadavri). Izolacija in gojenje celic iz tkiv mrtvih miši sta potekali pod standardnimi pogoji. Da bi ugotovili, katerim celičnim linijam pripadajo izolirane celice, je bil del celic uporabljen za izolacijo RNK in nadaljno uporabo v sistemu identifikacije izvornih celičnih linij z verižno reakcijo s polimerazo v realnem času. Rezultati naše raziskave so pokazali, da je žive celice mogoče izolirati iz mišičnega in možganskega tkiva 3 dni po smrti, pogojno tudi do 6 dni po smrti. Iz možganskega tkiva je bilo žive celice mogoče izolirati tudi do 9 dni po smrti. Iz maščobnega tkiva je bilo celice mogoče izolirati zgolj takoj po smrti, ne pa tudi v kasnejših časovnih intervalih. V vseh primerih so bile celice izolirane samo v primeru shranjevanja tkiv pri $4^{\circ} \mathrm{C}$. Oblika shranjenega tkiva na izolacijo celic $n$ vplivala. Izolirane celice so pripadale različnim zarodnim plastem. Rezultati raziskave so pokazali, da je žive celice iz mišjih trupel mogoče izolirati tudi več dni po smrti.

Ključne besede: miš; truplo; matične celice; možgansko tkivo; mišično tkivo; maščobno tkivo 